\title{
HIV-1 Tat acts as a processivity factor in vitro in conjunction with cellular elongation factors
}

\author{
Hiroyuki Kato, ${ }^{1}$ Hideki Sumimoto, ${ }^{1,3}$ Philippe Pognonec, ${ }^{1}$ Chein-Hwa Chen, ${ }^{2}$ Craig A. Rosen, ${ }^{2}$ \\ and Robert G. Roeder ${ }^{1,4}$ \\ ${ }^{1}$ Laboratory of Biochemistry and Molecular Biology, The Rockefeller University, New York, New York 10021 USA; \\ ${ }^{2}$ Department of Gene Regulation, Roche Institute of Molecular Biology, Nutley, New Jersey 07110 USA
}

The HIV-1 trans-activator Tat increases the rate of transcription from the HIV-1 LTR promoter through the stem-loop-containing TAR RNA. To analyze the mechanisms of Tat action, a cell-free trans-activation system with no preincubation has been developed. Recombinant Tat specifically increased the level of a long runoff transcript but not a promoter-proximal transcript in a TAR-dependent fashion. These observations and the result of pulse-chase experiments support strongly the hypothesis that Tat enhances the ability of RNA polymerase to elongate over longer distances. Increased levels of the purified cellular factor TFIIF, essential for initiation and also implicated in elongation of transcription, obviated trans-activation by Tat by increasing the basal (Tat-independent) activity. However, another elongation factor, ATN/TFIIS, showed synergistic activation with Tat. An antiserum against a recombinant form of the large subunit of TFIIF (RAP 74) preferentially suppressed the activated level of transcription exerted by Tat. We propose the hypothesis that Tat acts as a processivity factor on RNA polymerase II in an analogous manner to TFIIF.

[Key Words: HIV; Tat; trans-activation; clongation factor; processivity; TFIIF]

Received October 21, 1991; revised version accepted February 10, 1992

Trans-activation of the human immunodeficiency virus-1 (HIV-1) gene expression by the Tat protein, which is essential for HIV replication (Dayton et al. 1986; Fisher et al. 1986), has been studied extensively (for review, see Pavlakis and Felber 1990; Cullen 1991). Tat strongly activates gene expression from the HIV long terminal repeat (LTR) through the nascent trans-activation response (TAR) RNA structure (Berkhout et al. 1989; Selby and Peterlin 1990; Southgate et al. 1990/ present immediately downstream of the initiation site (Rosen et al. 1985; Cullen 1986; Muesing et al. 1987/. Sequences within the loop and the bulge, as well as the stem structure in TAR, have been shown to be required in cis for Tat action (Feng and Holland 1988; Jakobovits et al. 1988; Berkhout and Jeang 1989; Garcia et al. 1989). Whereas Tat binds directly to the bulge (Dingwall et al. 1990; Roy et al. 1990; Weeks et al. 1990), cellular proteins that recognize the loop sequence appear to be essential for Tat function on the natural TAR (Marciniak et al. 1990a). Although the actions of Tat appear to be bimodal (Cullen 1986), including transcriptional and translational stimulation (Rosen et al. 1986; Muesing et

\footnotetext{
${ }^{3}$ Present address: Department of Biochemistry, University of Kyushu School of Medicine, Higashi-ku, Fukuoka 812, Japan.

${ }^{4}$ Corresponding author.
}

al. 1987; Jakobovits et al. 1988; SenGupta et al. 1990), the major effect in mammalian cells is transcriptional (Hauber et al. 1987; Jakobovits et al. 1988; Rice and Mathews 1988). Detailed nuclear run-on experiments with an adenovirus vector have shown that Tat increases promoter-proximal transcription and also suppresses transcriptional polarity (Laspia et al. 1989). The primary point of action of this apparent dual effect is unclear. A report using a cell-free system (Marciniak et al. 1990b) suggested that the primary effect is an increase in elongation efficiency. The basis for this hypothesis was the observation that the amount of short transcripts does not increase significantly. More recent studies using the adenovirus vector (Laspia et al. 1990) and HIV virus-producing cells (Feinberg et al. 1991) emphasized elongational activation, essentially consistent with an earlier finding based on transient expression methods (Kao et al. 1987).

Two cellular factors, TFIF (also referred as RAP30/74, $\beta \gamma$, and FC) (Sopta et al. 1985; Conaway and Conaway 1989; Flores et al. 1990; Kitajima et al. 1990) and TFIIS (Sekimizu et al. 1976), have been reported to enhance transcriptional elongation in vitro (Reinberg and Roeder 1987; Flores et al. 1989). It was reported that TFIIS suppresses pausing and also releases the paused complex, whereas TFIIF suppresses only pausing with an increased rate of elongation (Bengal et al. 1991). Involvement of 
these factors in Tat trans-activation, however, remains to be studied.

To analyze Tat function in more detail and to elucidate the molecular mechanisms for trans-activation, we have used a cell-free transcription system (Weil et al. 1979). The results of previous reports with cell-free systems are complicated by the inability to reproduce in vivo specificities in vitro (Okamoto and Wong-Staal 1986; Jeyapaul et al. 1990; Okamoto et al. 1990) and by protocols involving a long preincubation without incorporation of labeled NTPs (Marciniak et al. 1990b). The latter might eliminate an effect on initiation or result in loss of activity of factors involved in trans-activation.

In this paper we report the development of a cell-free transcription protocol that does not require a preincubation step for activation and unequivocally show that Tat facilitates elongation of RNA polymerase. Toward understanding the molecular mechanisms of Tat action, the relationship between cellular factors required for transcriptional elongation and Tat-mediated stimulation was examined. Addition of purified TFIIF increased the basal level of elongation but not Tat-activated elongation and thereby masked Tat stimulation. In contrast, an antitermination activity, designated ATN/TFIIS, stimulated elongation synergestically with Tat. We therefore hypothesize that Tat stimulates or somehow mimics the activity of purified TFIIF. In addition, on the basis of studies with an antiserum against the large subunit of TFIIF, we discuss the possibility of direct Tat-mediated interactions with the TFIIF subunit.

\section{Results}

Tat specifically increases the level of a long runoff transcript from the HIV-1 promoter in vitro with no preincubation

In the course of developing a Tat-responsive cell-free system, we have paid attention to the suppression of basal level transcription as well as the specificity of Tat transactivation. The in vitro transcription activity of the HIV-1 promoter (Fig. 1A) is exceptionally high under standard conditions (Okamoto and Wong-Staal 1986; Marciniak et al. 1990b; Kato et al. 1991) despite the relatively low expression of the uninduced promoter in vivo (Sodroski et al. 1985). In addition, a strong transcriptional polarity observed for the HIV-1 promoter in vivo, with the coding sequences of either HIV-1 (Feinberg et al. 1991) or a heterologous gene (Laspia et al. 1989), is not evident in standard cell-free transcription systems.

We have found that citric acid at 6-8 $\mathrm{mm}$ decreases the efficiency of basal elongation and thereby highlights the trans-activation by Tat. Tat protein, expressed in Escherichia coli as a fusion protein with 6 histidine residues and highly purified by affinity chromatography, was used in this experiment (Fig. 1B) (Gentz et al. 1989). The wildtype Tat protein is biologically active, as demonstrated by both scrape-loading and simple addition of Tat to the culture medium (Gentz et al. 1989). Furthermore, this protein specifically binds to the bulge of the HIV-1 TAR with high affinity (Roy et al. 1990). Under the specified conditions (see Materials and methods), the recombinant Tat protein increased the level of long runoff transcripts $(\sim 1000$ nucleotides $)$ from the wild-type promoter $(\mathrm{HIV}+58$ with the promoter sequences -167 to +58 , $\mathrm{HIV}+51$ with -167 to +51 ; Fig. $1 \mathrm{~A}$ ) by 10 - to 15 -fold in a HeLa nuclear extract with no preincubation (Fig. 2A, lanes $1-4,11-14)$. Fifty nanograms of Tat raised the level up to $>50 \%$ of the plateau. Transcription from a TAR mutant in the loop (HIV $+51 \mathrm{M}$ with a 5-nucleotide substitution) or a 3 '-deletion mutant (HIV +23 ) containing a shorter leader sequence extending only to +23 (Fig. 1) was not increased at all (Fig. 2A, lanes 15-18,1-18). Both of these mutants were also inactive in vivo when tested by cotransfection with a Tat-producing plasmid (Fig. 2B, lanes 5,6) (Rosen et al. 1985), although HIV +58 and HIV +51 were fully activated (lanes 1-4). Mutant Tat proteins in which a cysteine residue at position 22 or 25 was changed to serine or arginine, respectively (Fig. 1), failed to activate transcription from any of the templates (Fig 2A, lanes 5-10), in agreement with in vivo results (Ruben et al. 1989).

To determine the rate of promoter-proximal transcription, the amount of RNA transcribed from the sequence immediately downstream of the initiation site was quantitated by RNase protection with unlabeled antisense RNA. The same runoff RNA samples as shown in Figure $2 \mathrm{~A}$ were analyzed, and products of 56,59, 30, and 23 nucleotides expected for $\mathrm{HIV}+58, \mathrm{HIV}+5 \mathrm{l}, \mathrm{HIV}+51 \mathrm{M}$, and $\mathrm{HIV}+23$, respectively, were obtained (Fig. 2C). Essentially the same signal intensity was detected for each set of samples with increased amounts of Tat /cf. lanes 2-10 with lane 1, lanes 12-14 with lane 11, and lanes 16-18 with lane 15). This suggests that the same number of RNA polymerase molecules elongated to nucleotide +56 , and this was independent of both the TAR sequence and Tat. By comparing directly the radioactivity (normalized to transcript length) of the runoff and the RNase-resistant transcripts, we estimate that in the absence of Tat, only 3-5\% of RNA polymerase molecules that pass +56 could traverse the transcription unit to give a full-length product (1000 nucleotides). Tat increased the percentage to $30-50 \%$. If the recovery of the short RNA in the RNase protection assay was significantly lower than $100 \%$ (e.g., because of inefficient hybridization, overdigestion by RNase A, or loss during ethanol precipitation), the real percentages would be smaller (note that the signals of the short RNAs increase). However, the recoveries were kept to maximum by optimizing the conditions for hybridization and digestion (data not shown). It appears that RNA polymerase terminates or pauses at multiple sites rather than at very specific sites. These results are compatible with those reported by Marciniak et al. (1990b), even though the conditions used here allow uniform labeling of transcripts.

It has been reported that Tat functions on the HIV-1 promoter with heterologous upstream sequences (Rosen et al. 1985; Cullen 1986; Peterlin et al. 1987). To see whether the in vitro reaction is also independent of spe- 


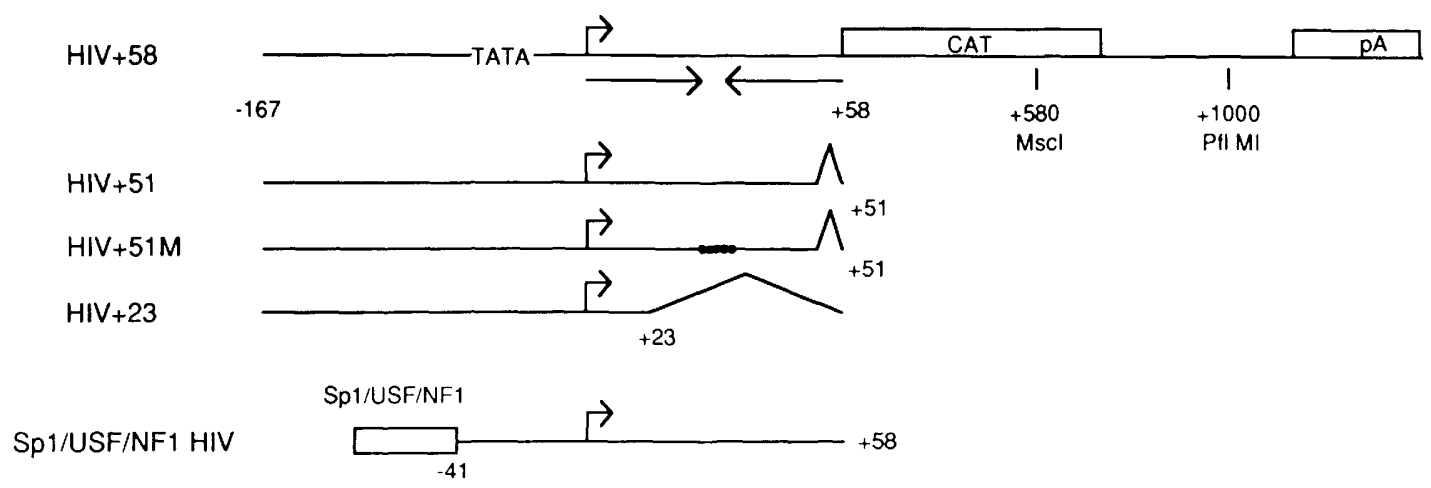

B

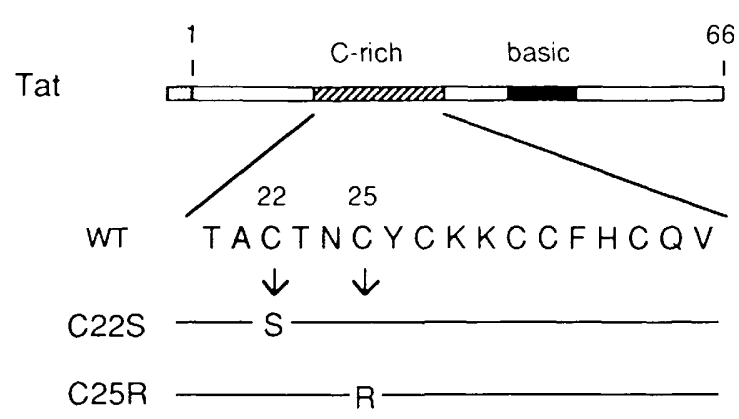

Figure 1. HIV-1 DNA templates and HIV-1 Tat protein derivatives. $(A)$ pHIV $+58, \mathrm{pHIV}+51$, pHIV $+51 \mathrm{M}$, and pHIV +23 contain HIV-I promoter sequences from -167 to the indicated $3^{\prime}$ border points, except that pHIV $+51 \mathrm{M}$ has a 5 -nucleotide change (GGGAG $\rightarrow$ TTTCT) in the sequence $(+31 /+35)$ of the TAR loop. SplHIV, USFHIV, and NF1HIV have the HIV-1 sequence from -41 to +58 with two Spl-, two USF-, or one NFl-binding site upstream $(-41$, DdeI $)$ of the HIV-1 TATA. All of the plasmids are linked to the CAT expression cassette (Rosen et al. 1985). Plasmids used for cell-free transcription were cut with PflMI to generate runoff transcripts of $\sim 1000$ nucleotides, except that pHIV +23 was cut with $M s c I$ to serve as an internal control transcript of 580 nucleotides. (B) Amino acid substitutions of Tat protein. The wild-type Tat protein with a histidine stretch (Tat) consisted of 66 amino acids derived from the first exon of HIV-1 (strain HXBC2). The Tat mutants (designated C22S or C25R) have a substitution of a single amino acid at residue 22 (cysteine to serine) or 25 (cysteine to arginine). C22S and C25R showed a null activity for trans-activation of HIV-1 promoter when transfected in HeLa cells (Ruben et al. 1989).

cific upstream elements, plasmids (pSp1HIV, pUSFHIV, and pNF1HIV) with Sp1-, USF-, or NF1-binding sites immediately upstream of the HIV-1 TATA sequence were tested. Although promoter activity of these constructs was somewhat lower than that of the wild-type promoter, the ratio of in vitro trans-activation was fairly uniform (5- to 10-fold) among each of the templates (Fig. 2D). This is consistent with in vivo results demonstrating that each of these promoters was activated to the same extent in HeLa cells (Fig 2B). Thus, it does not appear that certain upstream factors are specifically involved in the trans-activation.

\section{Elongating polymerase can be directly activated}

Although the rate of transcription in the promoter-proximal region is constant, it is possible that Tat does not act directly on the elongating RNA polymerase. To determine whether actively transcribing RNA polymerase is still capable of being stimulated by Tat, a pulse-chase experiment was performed. Preinitiation complexes were formed by preincubating the template with nuclear extract for $15 \mathrm{~min}$ and were then allowed to synthesize a short transcript of 13 nucleotides by incubating with dATP, GTP, UTP, and $\left[\alpha^{-32}\right.$ PJCTP for $1 \mathrm{~min}$. This reaction was followed by the addition of ATP, excess unlabeled CTP, and additional sodium citrate to final concentrations of $4.0,6.4$, or $8.8 \mathrm{~mm}$ in the absence or presence of Tat. In this chase reaction, Tat increased the level of the long runoff transcript by approximately threefold at each of the different sodium citrate concentrations (Fig. 3). With longer preincubation (>30 min), the extract was unable to support trans-activation. Inclusion of ATP during the pulse, which allows synthesis of longer transcripts, also abolished the stimulatory ac- 
tivity (data not shown), probably suggesting that transactivation occurs in the vicinity of the initiation site through the nascent RNA (Berkhout et al. 1989). Thus, at least part of Tat function appears to involve the direct activation of elongating RNA polymerase.

\section{TFIIF has a processivity activity}

To examine further the mechanism of Tat action on elongation, we investigated functional relationships between Tat and cellular elongation factors in the cell-free system.

Although described initially as an initiation factor, TFIIF was also reported to contain an elongation activity (Flores et al. 1989; Price et al. 1989), and highly enriched fractions of TFIIF that contained this activity (see Materials and methods) and were free of other initiation factors (Sumimoto et al. 1990) were used. Another elongation activity was purified further from the TFIIS activity described previously (see Materials and methods) and, on the basis of its antitermination activity (below), is referred to here as ATN/TFIIS.

To examine the properties of these elongation factors, a template immobilized on agarose by avidin-biotin interaction was used (Arias and Dynan 1989). Preinitiation complexes were isolated by incubating the immobilized template with nuclear extract for $30 \mathrm{~min}$ prior to washing four times with a buffer containing $0.1 \mathrm{M} \mathrm{KCl}$. TFIIF and ATN/TFIIS were then added independently to the preinitiation complexes, which were unable to elongate efficiently by themselves (Fig. 4A, lane 1). Addition of TFIIF increased moderately the level of the runoff transcript without significantly affecting the pattern of the multiple short transcripts (lanes 2-5). In contrast, in the presence of ATN/TFIIS, the amount of short transcripts was diminished and the level of the longer runoff transcript was increased markedly (lanes 7-10). This activity was saturated with the lowest amount of factors tested
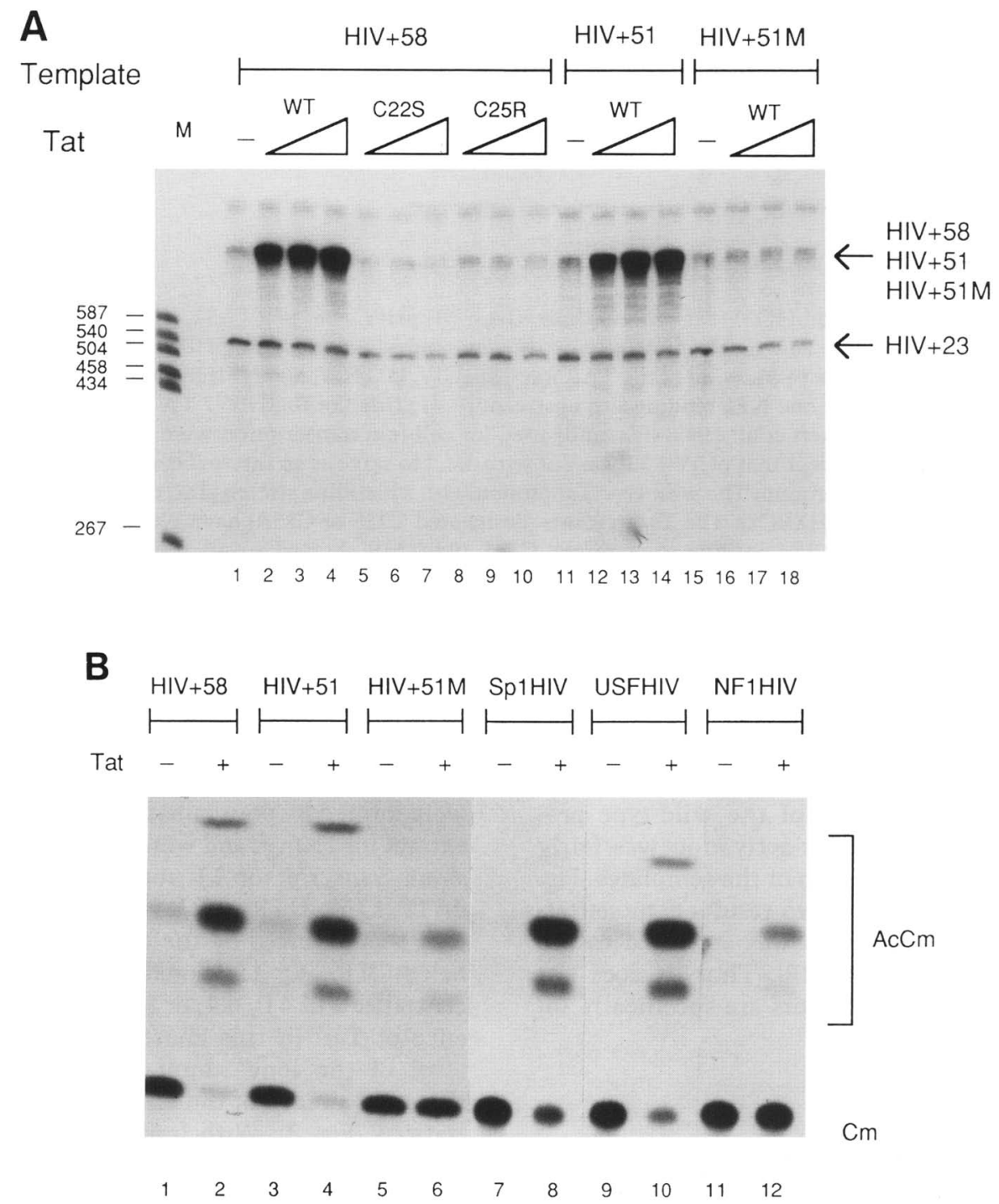

Figure 2. (Continued on facing page.) 
(lanes 2,7$)$, indicating a functional rather than a mere quantitative difference. To examine the effect of TFIIF and ATN/TFIIS on paused complexes, these factors were added to the immobilized templates containing RNA polymerase that had reached the pause sites (Fig. 4B). The paused complexes were obtained by incubating further the preinitiation complexes with four ribonucleoside triphosphates (rNTPs) containing $\left[\alpha-{ }^{32} \mathrm{P}\right] \mathrm{CTP}$ and by
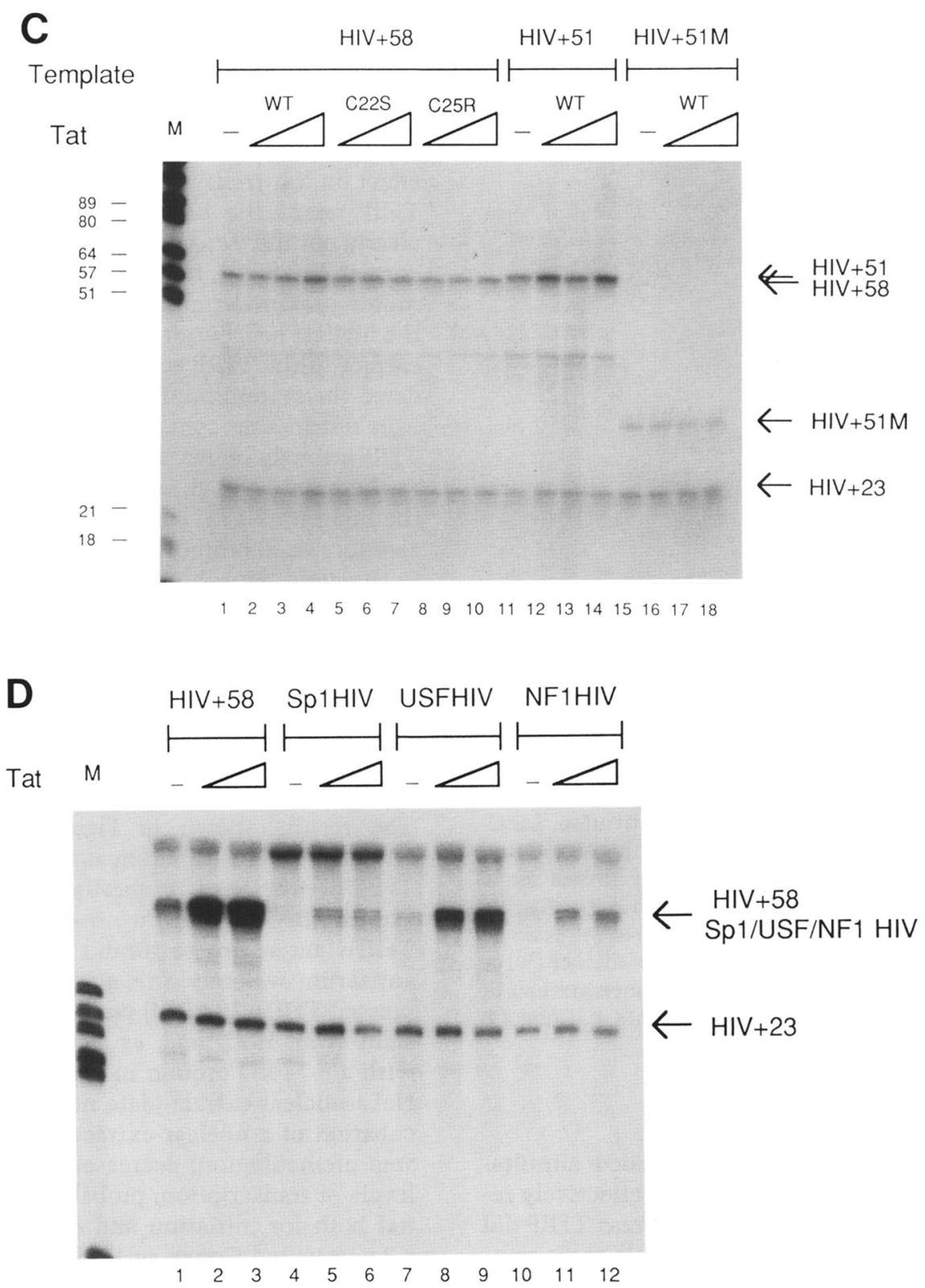

Figure 2. Specific trans-activation of HIV-1 transcription by Tat in vitro. (A) Runoff transcription. Reaction mixtures for in vitro transcription contain $100 \mathrm{ng}$ of one of the test templates (HIV $+58, \mathrm{HIV}+51$, or $\mathrm{HIV}+51 \mathrm{M}$ ), $100 \mathrm{ng}$ of $\mathrm{HIV}+23$ as a control, and increasing amounts $(0,50,100,200 \mathrm{ng})$ of the wild type or one of the mutant Tat proteins $(\mathrm{C} 22 \mathrm{~S}$ or $\mathrm{C} 25 \mathrm{R})$ as indicated. Accurate runoff transcripts resolved on a $4 \%$ polyacrylamide gel are marked by arrows. $(B)$ CAT activity from the HIV promoters. The activities were measured for $10 \mathrm{~min}$ (lanes 1-6) or $30 \mathrm{~min}$ (lanes 7-12). Plasmids carrying the HIV promoters with a control plasmid $(-\mid)$ or a Tat-producing plasmid $|+|$ were cotransfected in HeLa cells by a calcium coprecipitation method. The ratios of trans-activation in multiple experiments ranged from 50- to 200-fold for HIV + 58, HIV +51, SplHIV, and USFHIV, from 30- to 50-fold for NF1HIV, and from 0.5- to 3-fold for HIV+51M. Typical results are shown. $(C)$ RNase protection analysis for promoter-proximal transcription. The other half of the runoff transcripts shown in $A$ was analyzed in parallel by an RNase protection assay with cold antisense RNA synthesized from pBL +51 PS. Resulting products resolved on a $12 \%$ polyacrylamide gel are shown by arrows. The calculated lengths are 56 nucleotides for pHIV $+58,59$ nucleotides for $\mathrm{pHIV}+51,30$ nucleotides for $\mathrm{pHIV}+51 \mathrm{M}$, and 23 nucleotides for $\mathrm{pHIV}+23$. $(D)$ Transcription of HIV templates with heterologous upstream sequences. pHIV +58 , SplHIV, USFHIV, or NF1HIV, together with pHIV +23 , was transcribed with increasing amounts $\{0,50,200 \mathrm{ng})$ of Tat under the standard conditions. 

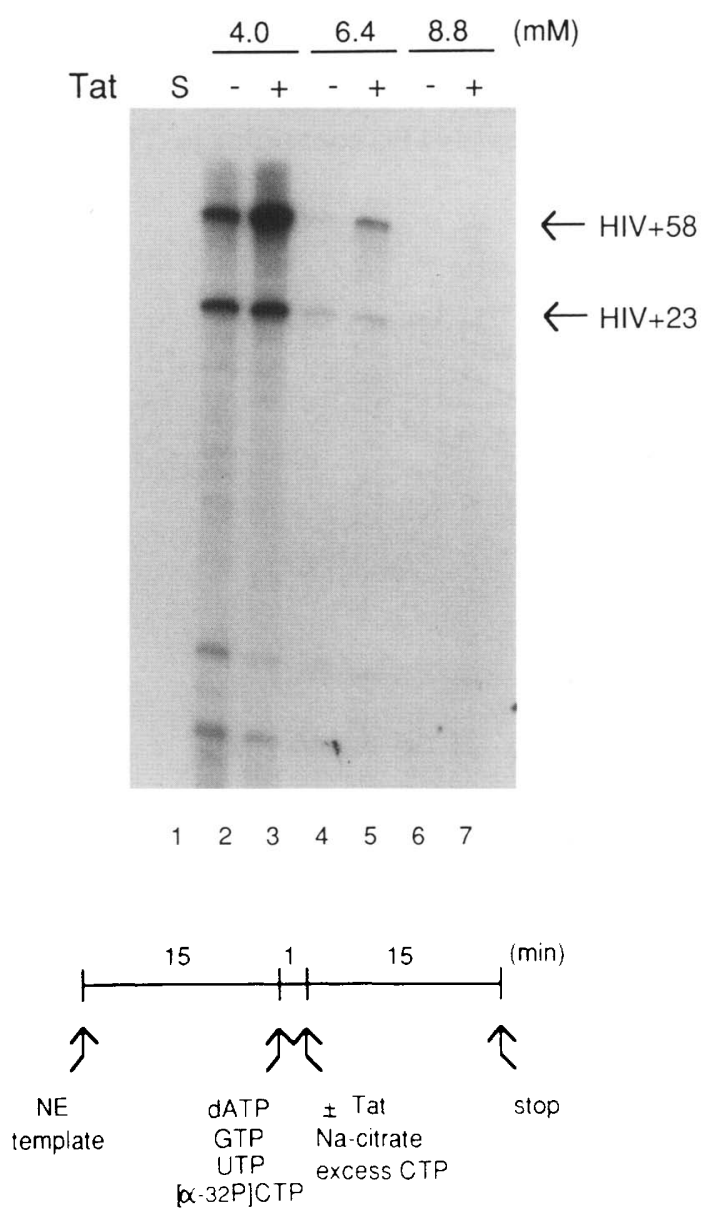

Figure 3. Pulse-chase analysis of Tat trans-activation. Labeling of a short (13-nucleotide) transcript from pHIV +58 and pHIV +23 was performed by incubating with a limited set of nucleotides (no ATP) containing the isotope after preincubation for $15 \mathrm{~min}$. The reaction was stopped $(S$, lane 1$)$ or followed by addition of ATP and unlabeled excess CTP in the absence $(-)$ or presence ( + ) of $200 \mathrm{ng}$ of Tat (lanes 2-7). Final concentrations of sodium citrate are $4 \mathrm{~mm}$ (lanes 2,3$), 6.4 \mathrm{~mm}$ (lanes 4,5$)$, and 8.8 mM (lanes 6,7).

another cycle of four washes. When added simultaneously with the four rNTPs, ATN/TFIIS effectively restarted elongation of the polymerase, whereas TFIIF did not (Fig. 4B). This suggests that the multiple short transcripts are not generated by premature termination but more likely by pausing, and ATN/TFIIS releases the pause.

In contrast to the results reported by Bengal et al. (1991) using the adenovirus major late promoter, TFIIF alone was unable to suppress pausing efficiently, even when present at the start of the reaction (Fig. 4A, cf. lane 1 with lanes $2-5$ ). This could be the result of intrinsic differences between the multiple pausing sites that are present in the chloramphenicol acetyltransferase (CAT) gene sequence and the single discrete site in the adenovirus major late gene or to differences in methods used to isolate the preinitiation and paused complexes. The
ATN/TFIIS activity, release of paused complex, may be viewed as an antitermination activity (Bengal et al. 1991). Here, we tentatively define the activity of TFIIF that is involved in the general promotion of elongation as processivity.

Tat acts on elongation in a manner that mimics the action of TFIIF

We then examined functional relationships between Tat and the elongation factors by testing their combinational effect on Tat trans-activation. Increasing the amount of TFIIF raised the basal level of runoff transcripts but clearly not the trans-activated level obtained in the presence of Tat (Fig. 5, lanes 1-6, top), without affecting promoter-proximal transcription (bottom). Thus, TFIIF at the highest concentration (equivalent to $20 \mu \mathrm{l}$ of nuclear extract in the TFIIF activity for accurate initiation) rendered the system nonresponsive to Tat.

In remarkable contrast to the effect of TFIIF, ATN/ TFIIS strongly increased the trans-activated level as well as the basal level at nearly comparable rates $(20$-fold at the highest) (Fig. 5, lanes $7-12,9^{\prime}-12^{\prime}$, top). ATN/TFIIS also increased promoter-proximal transcription by twoto threefold, probably because of a contaminating TFIIB activity. We therefore conclude that Tat functions on the polymerase, directly or indirectly, in a manner analogous to TFIIF (i.e., as a processivity factor) (Cullen 1990).

\section{Tat-mediated interactions on the large subunit of TFIIF}

The results shown in Figure 5 do not distinguish whether the Tat function is exerted somehow through TFIIF or whether it is totally independent of TFIIF. To address this question, we tested the ability of an antiTFIIF $\alpha$ antiserum to inhibit Tat trans-activation. The antiserum was raised in a rabbit against an E. coli-expressed TFIIF $\alpha$ (RAP74) protein (Aso et al. 1992; Finkelstein et al. 1992) and, as expected, reacted specifically with a $\sim 74-\mathrm{kD}$ protein in a Western blot analysis with HeLa nuclear extract (data not shown). A simple preincubation of a nuclear extract with the antiserum (onestep preincubation) decreased both basal and activated levels of transcription, probably because TFIIF is essential both for initiation and elongation of transcription (Conaway and Conaway 1989; Flores et al. 1990). However, the effect was more drastic on activated transcription (Fig. 6, cf. lanes 2 with 1, 4 with 3, and 6 with 5; approximately nine-, nine-, and threefold, respectively). Preincubation of a nuclear extract with template, which might be expected to preserve initiation complexes from the challenge by the antiserum, prior to a second incubation with the antiserum (two-step preincubation) restored the basal activity nearly to the level observed with PBS or preimmune serum (Fig. 6, cf. lane 11 with lanes 7 and 9). Perhaps antibodies attached to elongation complexes through TFIIF $\alpha$ do not impair elongation severely. Again, in this experiment, the fold activation in the reaction with anti-TFIIF $\alpha$ was significantly lower than 
A
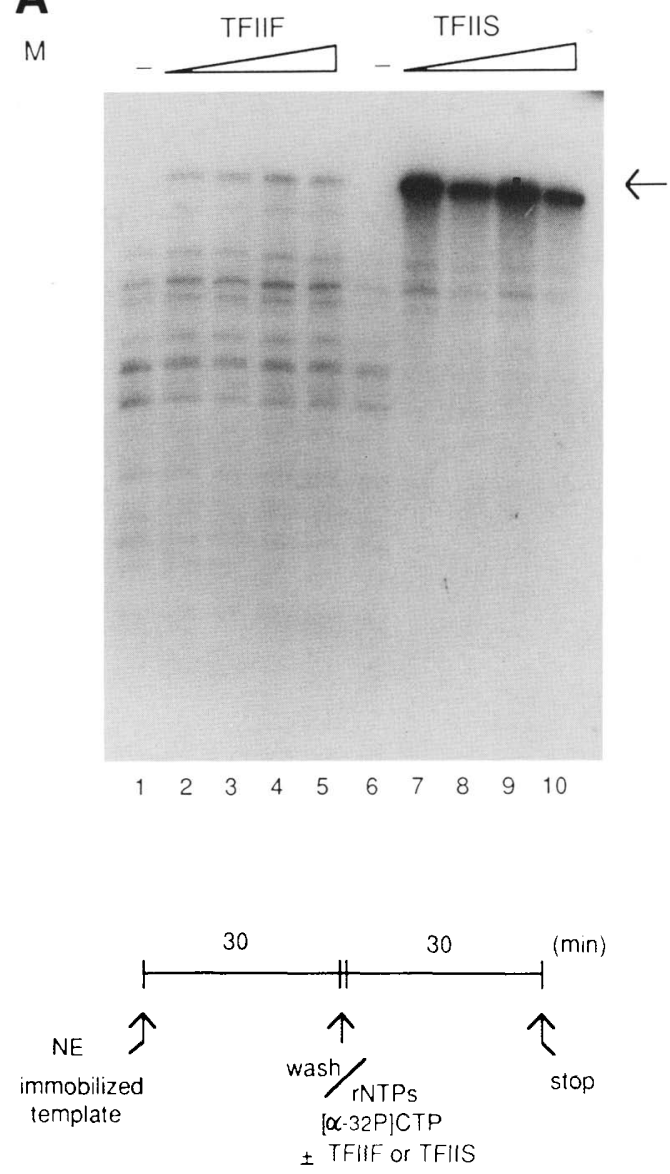
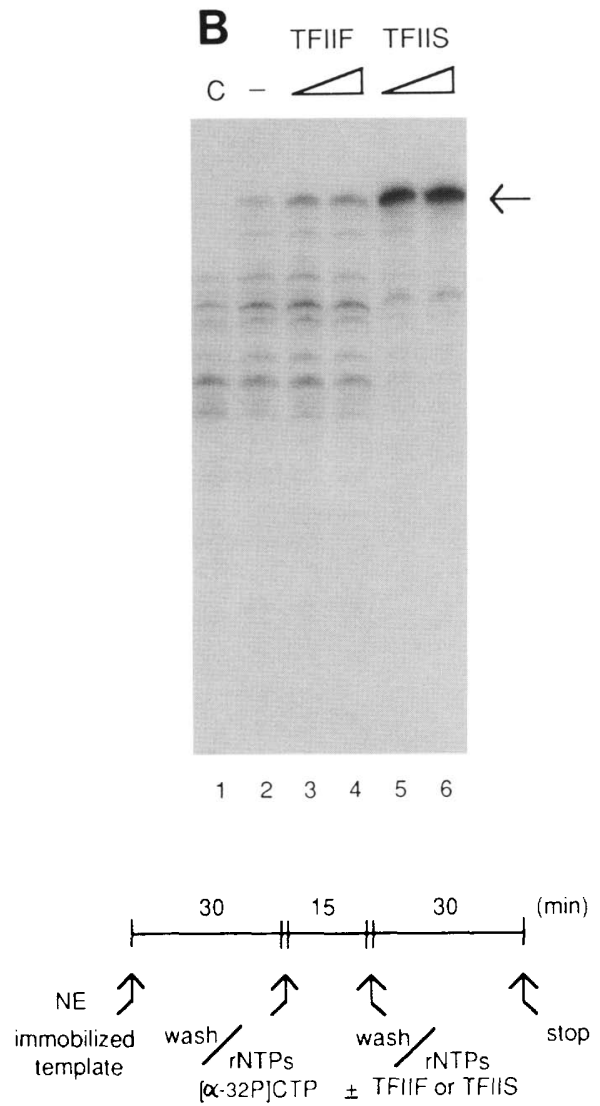

Figure 4. Functional properties of cellular elongation factors. (A) Effects of TFIIF and ATN/TFIIS on elongation of preinitiation complexes. Increasing amounts $(0,1.5,3.0,5.0,8.0 \mu \mathrm{l})$ of TFIIF (lanes 1-5) or ATN/TFIS (lanes $6-10$ ) were added to the isolated preinitiation complexes on the immobilized template of HIV + 58. Runoff transcripts are indicated by an arrow. $(B)$ Effects of TFIIF and ATN/TFIIS on elongation of paused complexes. Increasing amounts $(0,1.5,5.0 \mu l)$ of TFIIF (lanes 2-4) or ATN/TFIIS (lanes 2,5,6) were added to the isolated paused complexes $\{C$, lane 1$)$. These analyses and that of Fig. 5 used chromatographic fraction 3 of TFIIF (see Materials and methods).

that with PBS or preimmune serum/cf. lanes 8 with 7,10 with 9 , and 12 with 11 ; 4-, 4-, and 1.5 -fold, respectively). These results indicate that anti-TFIIF $\alpha$ antibody somehow inhibits TFIF $\alpha$-proximal interactions (directly or indirectly on TFIIF $\alpha$ ) required for the activation by Tat.

\section{Discussion}

We have developed an in vitro transcription system that reproduces the polarity of HIV transcription as well as the specific requirements observed in vivo for the target cis-acting TAR element and for the trans-activator Tat. We demonstrate unequivocally that Tat enhances the efficiency of elongation of RNA polymerase by showing that (1) promoter-proximal transcription is constant and (2) the elongating polymerase is able to be activated. Because the level of stimulation in the pulse-chase analysis (threefold) is significantly lower than that in the stan- dard reaction (10-fold) and because our in vitro conditions probably do not allow multiple rounds of initiation, we still do not formally exclude the possibility that Tat can stimulate the rate of initiation independently of or in conjunction with elongational stimulation. Enhancement of the rate of initiation (Laspia et al. 1989) could be a direct event, such as by an RNA-mediated enhancer (Sharp and Marciniak 1989), or a simple consequence of the clearance of jammed polymerases from the elongation pathway. Promoters with heterologous upstream activation elements can support Tat trans-activation, and an extensive search has provided no evidence for the existence of sequences specifically required for trans-activation, other than the upper part of TAR (Jakobovits et al. 1988; data not shown). Hence, the mechanism of Tat action does not appear to fit the model reported for the U1 small nuclear RNA (snRNA) transcription, in which a promoter sequence specifies the 3 '-end formation by RNA polymerase II (Hernandez and Weiner 1986; Neuman de Vegvar et al. 1986). The site of 


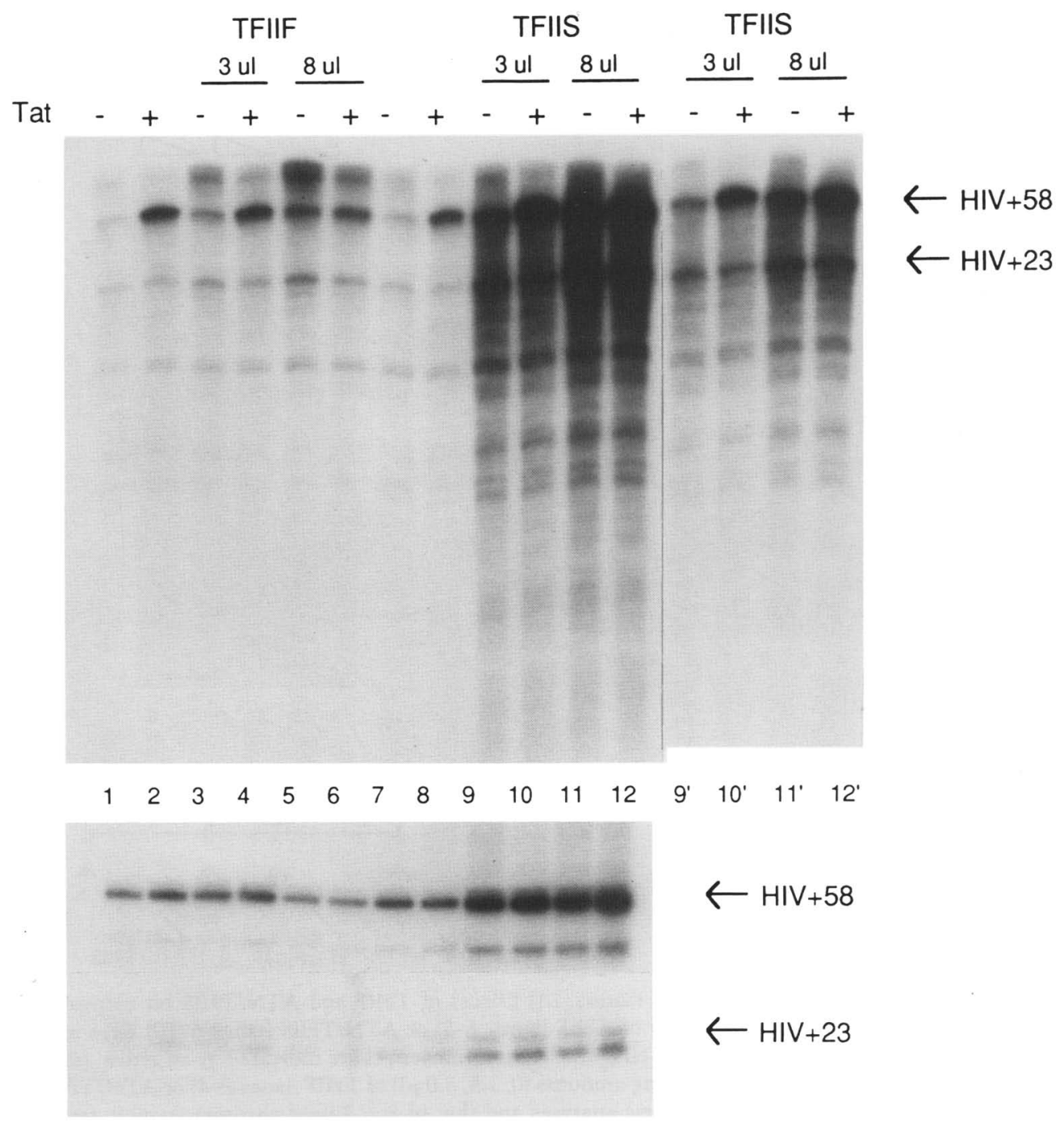

Figure 5. Functional similarity between Tat and cellular elongation factors. Increasing amounts $(0,3.0$, or $8.0 \mu l)$ of TFIIF (lanes $3-6)$ or ATN/TFIIS (lanes 9-12) were added to the standard reaction in the absence $(-)$ or presence $(+)$ of $150 \mathrm{ng}$ of Tat. The runoff transcripts (top) and the promoter-proximal transcripts (bottom) are shown as described in Fig. 2A,B. Shorter exposure of lanes $9-12$ is also shown in lanes $9^{\prime}-12^{\prime}$. The upper band in lanes $3-6$, which always appears upon addition of TFIIF fractions, is the nonspecific end-to-end transcript.

Tat function is probably restricted to the vicinity of the elongation complex.

TFIIF was shown first to be essential for the initiation of transcription (Burton et al. 1986; Conaway and Conaway 1989) and found later to (1) promote elongation (Flores et al. 1989) and (2) decrease the nonspecific binding activity of RNA polymerase II to double-stranded DNA (Conaway and Conaway 1990). Unlike TFIIS, TFIIF only suppresses pausing of the polymerase but does not restart the paused polymerase (Bengal et al. 1991), which is evidently observed in the experiment (Fig. 4) with the immobilized template. The most striking aspect of functional relationships between Tat trans-activation and cellular elongational control is that in nuclear extract, TFIIF stimulates basal level elongation but does not further stimulate Tat-activated elongation and, as a result, masks the trans-activation. Thus, Tat activity appears to be analogous to, and not additive with, the TFIIF function as a processivity factor. ATN/TFIIS, in turn, exhibits elongational stimulation in synergy with Tat. These observations may be interpreted as a subsidiary action of Tat on TFIIF (e.g., increasing the local concentration of TFIIF or stabilizing TFIIF binding to RNA polymerase) through an interaction between Tat and TFIIF. Alternatively, Tat may somehow mimic TFIIF function by itself or through other cellular factors. In both cases, the presence of high concentrations of TFIIF can render Tat unable to enhance the processivity further.

The preferential inhibition of Tat-activated transcription by the anti-TFIIF $\alpha$ antiserum could reflect a block of Tat-mediated interactions (of unidentified proteins) on TFIIF $\alpha$. Alternatively, the antibody could sterically in- 


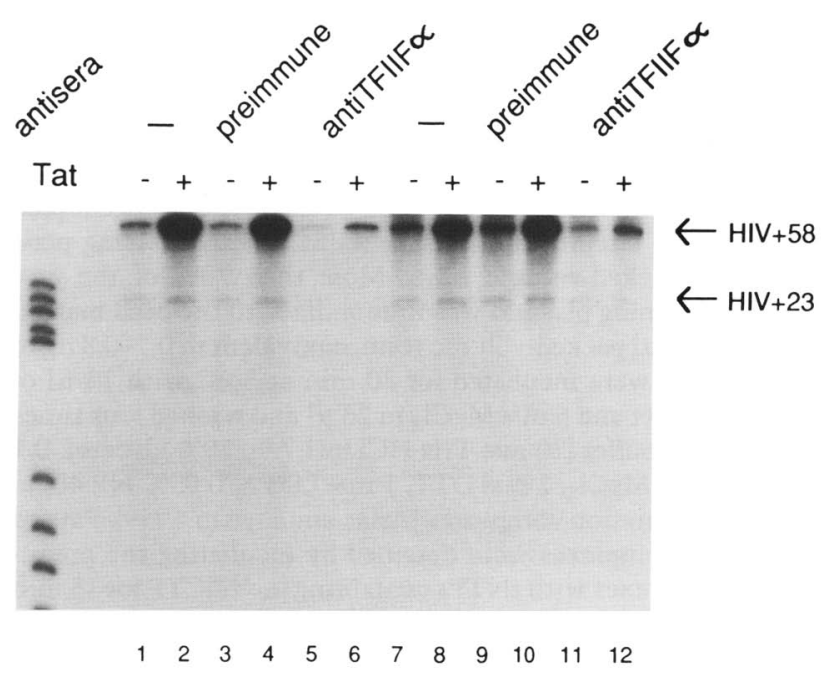

Figure 6. Preferential inhibition of trans-activation by an antiserum against the large subunit of TFIIF. After one-step (lanes 1-6) or two-step (lanes 7-12) preincubation (see Materials and methods|, transcription reaction was allowed to start under the standard conditions in the absence $|-|$ or presence $|+|$ of $150 \mathrm{ng}$ of Tat. The same amount $(2 \mu$ l) of PBS (lanes 1,2, 7,8), rabbit preimmune serum (lanes $3,4,9,10$ ), or anti-TFIIF $\alpha$ serum (lanes $5,6,11,12 \mid$ was included in the preincubations.

terfere with Tat-mediated interactions in the proximity of (but not directly on) TFIIF $\alpha$. Further experiments with several monoclonal antibodies that independently recognize TFIIF subunits and other components in elongation complexes (such as RNA polymerase II and TFIIS) may discriminate among these possibilities.

It is noteworthy that the possible dual actions of Tat on initiation and elongation resemble TFIIF function. This may provide an answer to the indication that Tat also might affect directly the process of initiation complex formation (Laspia et al. 1989; Southgate and Green 1991). Another observation of potential relevance is that the partially purified RAP30/74 (TFIIF) fraction has an ATP-dependent DNA helicase activity (Sopta et al. 1989|, probably not the result of TFIIF itself, but associated (copurified) factors (Flores et al. 1990). Whether the two proteins $(30$ and $74 \mathrm{kD})$ in the TFIIF activities are sufficient to provide the processivity will be clarified after further characterization.

With the evidence available from in vivo and in vitro studies, we have considered three possibilities (not necessarily mutually exclusive) for the mechanisms of elongational activation by Tat. First, Tat may interact with RNA polymerase directly or through cellular elongation factors. There is a well-studied prokaryotic precedent in the bacteriophage $\lambda \mathrm{N}$ protein that facilitates $E$. coli RNA polymerase to read through some defined termination sites (for review, see Roberts 1988). N protein forms a complex with the RNA polymerase and host factors in a manner dependent on a promoter-proximal RNA sequence (nut) (Barik et al. 1987; Horwitz et al. 1987). Second, Tat may modify a protein within the elongation complex by using a cellular enzyme such as a kinase. Phosphorylation of RNA polymerase II (for review, see Corden 1990) or other cellular proteins (Nakanishi et al. 1981; Sopta et al. 1985) may be involved in the transactivation. Third, Tat may effect structural changes within or covalent modifications of the transcript. It was proposed that the secondary structure of a nascent RNA chain can affect the elongational property of RNA polymerase II (Resnekov et al. 1989). From a similarity of the target structure and the implicated complex formation with RNA polymerase, the mode of Tat action seems to be close to the first one.

Studies of Tat have revealed a unique example of a viral protein that interferes with a cellular process of transcriptional elongation. To test our hypothesis that Tat acts as a processivity factor like TFIIF and to analyze further the mechanisms of Tat action in detail, a system reconstituted with individual factors involved in the trans-activation will be used in the future. The attempt has been hampered so far by the requirement of multiple factors, including basic transcription factors, upstream activators, TAR RNA-binding proteins (Marciniak et al. 1990a), and possibly other accessory factors. Fusion proteins of Tat with other RNA-binding proteins /Selby and Peterlin 1990; Southgate et al. 1990) may circumvent this complexity partially. Alternatively, a clear picture may result from genetic studies on the corresponding factors as well as experiments demonstrating a physical interaction.

\section{Materials and methods}

\section{Plasmid constructions}

All template plasmids are derivatives of the CAT expression plasmid p-167 containing the HIV-1 promoter sequences (Rosen et al. 1985). pHIV +58 was described previously (Kato et al. 1991). pHIV +51 and pHIV $+51 \mathrm{M}$ were constructed by inserting oligonucleotides of the wild-type and mutant HIV-1 sequences $(-17$ to +51$)$ between the PvuII site $(-17)$ and the HindIII site $(+80)$ of p-167: pHIV +23 is a $3^{\prime}$ deletion mutant at the BglII site $(+23)$. The plasmids (pSplHIV, pUSFHIV, and pNF1HIV) with two Spl-, two USF-, and one NFl-binding site, respectively, have the following sequences immediately upstream $\mid-41$, DdeI) of the HIV-1 TATA element: Spl, TCGAGGGGCGGGGTGGGGCGGGGT; USF, TCGAGGCCACGTGACCGGCCACGTGACC; NF1，TCGAGTTGGCACTGTGCCAG. pBL + 51PS was constructed by inserting the PvuII $(-17) /$ SalI $(+51)$ fragment of pHIV +51 between HindIII and EcoRI sites of pBluescript SKII $\mid-$ ).

\section{Preparation of Tat and elongation factors}

The expression of the histidine-tailed Tat proteins in E. coli and the purification through nickel-agarose chromatography were performed as described (Gentz et al. 1989), except that $50 \mathrm{~mm}$ imidazole was used for elution instead of low $\mathrm{pH}$. Tat proteins were further treated and renatured. Typically, a sample of $1 \mathrm{mg}$ of eluted Tat protein $[0.3-1.0 \mathrm{mg} / \mathrm{ml})$ was treated with $6 \mathrm{M}$ guanidine- $\mathrm{HCl}$ and $10 \mathrm{mM} \mathrm{DTT}$ at $50^{\circ} \mathrm{C}$ for $10 \mathrm{~min}$, followed by extensive dialysis at $4^{\circ} \mathrm{C}$ for $8-12 \mathrm{hr}$ against $4 \times 300 \mathrm{ml}$ of buffer [20 mM Tris- $\mathrm{HCl}(\mathrm{pH} 7.9$ ), 20\% glycerol, $0.5 \mathrm{~mm}$ EDTA, $5 \mathrm{~mm}$ 2 -mercaptoethanol, $300 \mathrm{mM} \mathrm{KCl}, 0.1 \% \mathrm{NP}-40$ ). The dialysate 
was centrifuged at $8000 \mathrm{~g}$ for $20 \mathrm{~min}$ to remove aggregates that cause nonspecific inhibition of transcription, and the resulting preparation was frozen in liquid nitrogen.

TFIIF was purified as reported previously (Sumimoto et al. $1990)$ and was used after the first or second high protein liquid chromatography (HPLC) DEAE-5PW columns (third and fifth chromatographic fractions, respectively). Although not purified to homogeneity, these fractions contained the same elongation activity as that reported by Flores et al. (1989) to be present in a more purified TFIIF preparation and to be inhibited by an antibody to one of the known subunits (RAP30) of TFIIF. The experiments of Figures 4 and 5 used TFIIF from the first HPLC DEAE-5PW column, although identical results were obtained with the more purified fractions from the second HPLC DEAE5PW column (data not shown).

The antitermination activity present in the TFIIS fraction reported previously (Reinberg and Roeder 1987) was purified with modifications as follows. The phosphocellulose $0.5 \mathrm{M} \mathrm{KCl}$ fraction was applied to DEAE-cellulose equilibrated with $0.1 \mathrm{M}$ $\mathrm{KCl}$. The flowthrough fraction was passed through singlestranded DNA-agarose at $0.15 \mathrm{M} \mathrm{KCl}$ and was subjected to chromatography an HPLC heparin-5PW column, from which it was eluted with $0.34 \mathrm{M} \mathrm{KCl}$. Because the antitermination activity in this fraction has not been proved to be equivalent to that reported for the corresponding cloned form of SII /Hirashima et al. 1988 |, we referred to the activity simply as ATN/TFIIS.

\section{Prepation of rabbit anti-TFIIF $\alpha$ antisera}

TFIIF $\alpha$ cDNA with 6 histidine residues at the amino terminus was inserted in pET11d (Hoffmann and Roeder 1991). The bacterial pellet was sonicated in lysis buffer (Pognonec et al. 1991) and lysed by the addition of $6 \mathrm{M}$ guanidium- $\mathrm{HCl}$. Recombinant TFIIF $\alpha$ was then purified by nickel-agarose chromatography (Hoffmann and Roeder 1991) and dialyzed against PBS prior to injection in rabbit. A New Zealand white rabbit was initially injected intradermally with $300 \mu \mathrm{g}$ of the antigen (TFIIF $\alpha$ ) / as an emulsion with an equal volume of Freund's complete adjuvant) and boosted subcutaneously at 3-week intervals with $150 \mu \mathrm{g}$ of the antigen (as an emulsion with an equal volume of Freund's incomplete adjuvant). The serum used in this experiment was obtained 2 months after the initial injection.

\section{In vitro transcription and pulse-chase analysis}

Cell-free transcription $(25 \mu \mathrm{l})$ was performed for $30 \mathrm{~min}$ at $30^{\circ} \mathrm{C}$ with $12 \mu \mathrm{l}(10 \mathrm{mg} / \mathrm{ml})$ of HeLa cell nuclear extract (Dignam et al. 1983) and 100 ng each of the two linear templates. The standard reaction mixtures included $15 \mathrm{~mm}$ Tris- $\mathrm{HCl}(\mathrm{pH} 7.9), 15 \%$ glycerol, $0.4 \mathrm{~mm}$ EDTA, $6 \mathrm{~mm} \mathrm{MgCl}, 6 \mathrm{~mm}$ sodium citrate $(\mathrm{pH}$ $6.7), 100 \mathrm{~mm} \mathrm{KCl}, 0.05 \%$ NP-40, 10 units of RNasin (Promega), $100 \mu \mathrm{M}$ ATP, GTP, and UTP, as well as $10 \mu \mathrm{M}(5 \mu \mathrm{Ci})\left[\alpha^{-}{ }^{32} \mathrm{P}\right] \mathrm{CTP}$ (3000 Ci/mmole, Amersham). Earlier studies with $\left[\alpha^{-32} \mathrm{P}\right]$ GTP gave fluctuation in the level of accurate transcription and highmolecular-mass backgrounds according to batch differences in the isotope. The final concentration of each compound in the experiment with different amounts of Tat or elongation factors was compensated by the addition of the same buffer. Each half of the processed RNA sample was resolved by $4 \%(30: 1)$ polyacrylamide- $8 \mathrm{M}$ urea gel electrophoresis.

For the pulse-chase analysis, preincubation for $15 \mathrm{~min}$ under the standard conditions with $4 \mathrm{~mm}$ sodium citrate, but without the NTPs, was followed by 1 -min pulses with $100 \mu \mathrm{M}$ each of dATP, GTP, and UTP and $0.1 \mu \mathrm{M}\left[\alpha^{-}{ }^{32} \mathrm{P}\right] \mathrm{CTP}$. The chase involved addition of $100 \mu \mathrm{M}$ ATP, $400 \mu \mathrm{M}$ CTP, and $0-4.8 \mathrm{~mm}$ additional sodium citrate in the absence or presence of $200 \mathrm{ng}$ of Tat for $15 \mathrm{~min}$.

The immobilized template was prepared as described (Arias and Dynan 1989). pHIV +58 cut at the XhoI site $(-167)$ was filled in with biotinylated dUTP (Boehringer Mannheim) and cut with PflMI. The biotinylated DNA fragments were coupled directly with streptavidin-agarose (GIBCO-BRL) at $1 \mathrm{mg}$ plas$\mathrm{mid} / 4 \mathrm{ml}$ packed-volume resin. More than $70 \%$ of the promoter-containing plasmid was immobilized to the bead matrix. The beads $(4 \mu \mathrm{l}$ packed-volume resin, equivalent to $0.7-0.8 \mu \mathrm{g}$ of the plasmid) were incubated for $30 \mathrm{~min}$ at $30^{\circ} \mathrm{C}$ with $12 \mu \mathrm{l}$ of nuclear extract and $6 \mathrm{mM} \mathrm{MgCl}_{2}$ in $25 \mu \mathrm{l}$ and washed four times with a wash buffer $[20 \mathrm{mM}$ Tris- $\mathrm{HCl}(\mathrm{pH} 7.9), 20 \%$ glycerol, 0.1 $\mathrm{M} \mathrm{KCl}, 8 \mathrm{~mm} \mathrm{MgCl}_{2}, 2 \mathrm{~mm}$ DTT, $1 \mathrm{~mm}$ EDTA, $\left.0.05 \% \mathrm{NP}-40\right]$ to obtain preinitiation complexes (Arias and Dynan 1989). Paused elongation complexes were obtained by incubating the preinitiation complexes with $\mathrm{rNTPs}$ containing $\left[\alpha^{-32} \mathrm{P}\right] \mathrm{CTP}$ for $15 \mathrm{~min}$ and washing four times. The beads with preinitiation or paused complexes in $15 \mu \mathrm{l}$ of the wash buffer were directly assayed by incubating for $30 \mathrm{~min}$ with elongation factors and rNTPs containing $\left[\alpha-{ }^{32} \mathrm{P}\right] \mathrm{CTP}$.

For one-step preincubation, $12 \mu \mathrm{l}$ of nuclear extract was incubated with $2 \mu \mathrm{l}$ of serum (or PBS) on ice for $50 \mathrm{~min}$. For two-step preincubation, $12 \mu \mathrm{l}$ of nuclear extract was incubated first with the templates and $6 \mathrm{mM} \mathrm{MgCl}_{2}$ at $30^{\circ} \mathrm{C}$ for $25 \mathrm{~min}$ and second with $2 \mu \mathrm{l}$ of serum (or PBS) on ice for $50 \mathrm{~min}$. These preincubations were followed by the standard reaction.

\section{RNase protection assay}

The antisense cold RNA probe was synthesized with T3 polymerase (Promega) from HindIII-linearized pBL +51 PS. The other half of the labeled transcripts was hybridized for $3 \mathrm{hr}$ at $37^{\circ} \mathrm{C}$ with $100 \mathrm{ng}$ of the antisense probe in $20 \mu \mathrm{l}$ of $40 \mathrm{mM}$ PIPES (pH 6.7), $1 \mathrm{~mm}$ EDTA, $0.4 \mathrm{M} \mathrm{NaCl}$, and $80 \%$ formamide. The hybridized samples were diluted with 15 volumes $(300 \mu l)$ of an ice-cold buffer [ $10 \mathrm{~mm}$ Tris- $\mathrm{HCl}$ (pH 7.4), $5 \mathrm{~mm}$ EDTA, $300 \mathrm{~mm}$ $\mathrm{NaCl}, 6 \mu \mathrm{g} / \mathrm{ml}$ of RNase A (Boehringer Mannheim)/ and incubated for $30 \mathrm{~min}$ at $37^{\circ} \mathrm{C}$. The products, after extraction with phenol-chloroform $(1: 1)$ and chloroform, and ethanol precipitation, were analyzed on $12 \%(20: 1)$ polyacrylamide- $8 \mathrm{M}$ urea gels.

\section{Transfection and CAT assay}

Transfection was performed with $5 \mu \mathrm{g}$ of a reporter plasmid and $5 \mu \mathrm{g}$ of $\mathrm{pBC} 12 / \mathrm{CMV} / \mathrm{t} 2$ (Cullen 1986) in HeLa cells by the calcium phosphate precipitation method with osmotic shock with $15 \%$ glycerol in PBS. Cells were harvested after $40-48 \mathrm{hr}$ and processed by three cycles of freezing/thawing to obtain extracts. Ten micrograms of extract protein was incubated at $37^{\circ} \mathrm{C}$ for 10 or $30 \mathrm{~min}$ with $0.1 \mu \mathrm{Ci}$ of $\left|{ }^{14} \mathrm{C}\right| \mathrm{chloramphenicol}$ and $1 \mathrm{mM}$ acetyl coenzyme A in $100 \mu \mathrm{l} 0.25 \mathrm{M}$ Tris- $\mathrm{HCl}(\mathrm{pH} 7.5)$.

\section{Acknowledgments}

We are grateful to Sherman $M$. Weissman, Yukio Yasukochi, and Shigetaka Kitajima for providing the TFIIF $\alpha$ cDNA clone prior to publication and to Nobuo Horikoshi and Roberto Weinmann for helpful discussion and sending materials. We thank Sohail Malik for critical comments on the manuscript. Deoxyoligonucleotides were synthesized by the Protein Sequence Facility of the Rockefeller University. This work was supported by National Institutes of Health grants CA42567 and AI27397 to R.G.R. and by general support from the Pew Trusts to The 
Rockefeller University. H.K. was supported by a Cancer Research Institute fellowship and in part by the Mochida Memorial Foundation for Medical and Pharmaceutical Research. P.P. was supported by a European Molecular Biology Organization postdoctoral long-term fellowship.

The publication costs of this article were defrayed in part by payment of page charges. This article must therefore be hereby marked "advertisement" in accordance with 18 USC section 1734 solely to indicate this fact.

\section{References}

Arias, J.A. and W.S. Dynan. 1989. Promoter-dependent transcription by RNA polymerase II using immobilized enzyme complexes. J. Biol. Chem. 264: 3223-3229.

Aso, T., H.A. Vasavada, T. Kawaguchi, F.J. Germino, S. Ganguly, S. Kitajima, S.M. Weissman, and Y. Yasukochi. 1992. Characterization of cDNA for the large subunit of the transcription factor TFIIF. Nature 355: 461-464.

Barik, S., B. Ghosh, W. Whalen, D. Lazinski, and A. Das. 1987. An antitermination protein engages the elongating transcription apparatus at a promoter-proximal recognition site. Cell 50: 885-899.

Bengal, E., O. Flores, A. Krauskopf, D. Reinberg, and Y. Aloni. 1991. Role of the mammalian transcription factors IIF, IIS and IIX during elongation by RNA polymerase II. Mol. Cell. Biol. 11: 1195-1206.

Berkhout, B. and K.-T. Jeang. 1989. Trans-activation of human immunodeficiency virus type $l$ is sequence specific for both the single-stranded bulge and loop of the trans-acting-responsive hairpin: A quantitative analysis. J. Virol. 63: 55015504.

Berkhout, B., R.H. Silverman, and K.-T. Jeang. 1989. Tat transactivates the human immunodeficiency virus through a nascent RNA target. Cell 59: 273-282.

Burton, Z.F., L.G. Ortolan, and J. Greenblatt. 1986. Proteins that bind to RNA polymerase II are required for accurate initiation of transcription at the adenovirus 2 major late promoter. $E M B O$ /. 5: 2923-2930.

Conaway, J.W. and R.C. Conaway. 1989. A multisubunit transcription factor essential for accurate initiation by RNA polymerase II. J. Biol. Chem. 264: 2357-2362.

. 1990. An RNA polymerase II transcription factor shares functional properties with Escherichia coli $\mathrm{o}^{70}$. Science 248: $1550-1553$.

Corden, J.F. 1990. Tails of RNA polymerase II. Trends Biochem. Sci. 15: 383-387.

Cullen, B.R. 1986. Trans-activation of human immunodeficiency virus occurs via a bimodal mechanism. Cell 46: 973-982.

1990. The HIV-1 Tat protein: An RNA sequence-specific processivity factor? Cell 63: 655-657.

- 1991. Regulation of HIV-1 gene expression. FASEB I. 5: $2361-2368$

Dayton, A.I., J.G. Sodroski, C.A. Rosen, W.C. Goh, and W.A Haseltine. 1986. The trans-activator gene of human T-cell lymphotropic virus type III is required for virus replication. Cell 44: 941-947.

Dignam, J.D., R.M. Levovitz, and R.G. Roeder. 1983. Accurate transcription initiation by RNA polymerase II in a soluble extract from isolated mammalian nuclei. Nucleic Acids Res. 11: 1475-1489.

Dingwall, C., I. Ernberg, M.J. Gait, S.M. Green, S. Heaphy, J. Karn, A.D. Lowe, M. Singh, and M.A. Skinner. 1990. HIV-1 tat protein stimulates transcription by binding to a U-rich bulge in the stem of the TAR RNA structure. EMBO $J$. 9: $4145-4153$.
Feinberg, M.B., D. Baltimore, and A.D. Frankel. 1991. The role of Tat in the human immunodeficiency virus life cycle indicates a primary effect on transcriptional elongation. Proc. Natl. Acad. Sci. 88: 4045-4049.

Feng, S. and E.C. Holland. 1988. HIV-1 tat trans-activation requires the loop sequence within tar. Nature 334: 165-168.

Finkelstein, A., C.F. Kostrub, J. Li, D.P. Chavez, B.Q. Wang, S.M. Fang, J. Greenblatt, and Z.F. Burton. 1992. A cDNA encoding RAP74, a general initiation factor for transcription by RNA polymerase II. Nature 355: 464-467.

Fisher, A.G., M.B. Feinberg, S.F. Josephs, M.E. Harper, L.M. Marselle, G. Reyes, M.A. Gonda, A. Aldovini, C. Debouk, R.C. Gallo, and F. Wong-Staal. 1986. The trans-activator gene of HTLV-III is essential for virusreplication. Nature 320: $367-371$

Flores, O., E. Maldonado, and D. Reinberg. 1989. Factors involved in specific transcription by mammalian polymerase II: Factors IIE and IIF independently interact with RNA polymerase II. J. Biol. Chem. 264: 8913-8921.

Flores, O., I. Ha, and D. Reinberg. 1990. Factors involved in specific transcription by mammalian RNA polymerase II. $/$. Biol. Chem. 265: 5629-5634.

Garcia. J., D. Harrich, E. Soultanakis, F. Wu, R. Mitsuyasu, and R.B. Gaynor. 1989. Human immunodeficiency virus type 1 LTR TATA and TAR region sequences required for transcriptional regulation. $E M B O /$. 8: 765-778.

Gentz, R., C.-H. Chen, and C.A. Rosen. 1989. Bioassay for transactivation using purified human immunodeficiency virus tat-encoded protein: Trans-activation requires mRNA synthesis. Proc. Natl. Acad. Sci. 86: 821-824.

Hauber, J., A. Perkins, E.P. Heimer, and B.R. Cullen. 1987. Trans-activation of human immunodeficiency virus gene expression is mediated by nuclear events. Proc. Natl. Acad. Sci. 84: 6364-6368.

Hernandez, N. and A.M. Weiner. 1986. Formation of the $3^{\prime}$ end of U1 snRNA requires compatible snRNA promoter element. Cell 47: 249-258.

Hirashima, S., H. Hirai, Y. Nakanishi, and S. Natori. 1988. Molecular cloning and characterization of cDNA for eukaryotic transcription factor S-II. I. Biol. Chem. 263: 3858-3863.

Hoffmann, A. and R.G. Roeder. 1991. Purification of his-tagged proteins in non-denaturing conditions suggests a convenient method for protein interaction studies. Nucleic Acids Res. 19: 6337-6338.

Horwitz, R.J., J. Li, and J. Greenblatt. 1987. An elongation control particle containing the $\mathrm{N}$ gene transcriptional antitermination protein of bacteriophage lambda. Cell 51: 631-641.

Jakobovits, A., D.H. Smith, E.B. Jakobovits, and D.J. Capon. 1988. A discrete element 3' of human immunodeficiency virus 1 (HIV-1) and HIV-2 mRNA initiation sites mediates transcriptional activation by an HIV trans activator. Mol. Cell. Biol. 8: 2555-2561.

Jeyapaul, J., M.R. Reddy, and S.A. Khan. 1990. Activation of synthetic tat peptides in human immunodeficiency virus type 1 long terminal repeat-promoted transcription in a cellfree system. Proc. Natl. Acad. Sci. 87: 7030-7034.

Kao, S.-Y., A.F. Calman, P.A. Luciw, and B.M. Peterlin. 1987. Anti-termination of transcription within the long terminal repeat of HIV-1 by tat gene product. Nature 330: $489-493$.

Kato, H., M. Horikoshi, and R. G. Roeder. 1991. Repression of HIV-1 transcription by a cellular protein. Science 251: 14761479.

Kitajima, S., Y. Tanaka, T. Kawaguchi, T. Nagaoka, S.M. Weissman, and Y. Yasukochi. 1990. A hetelomeric transcription factor required for mammalian RNA polymerase II. Nucleic Acids Res. 18: 4843-4849. 
Laspia, M.F., A.P. Rice, and M.B. Mathews. 1989. HIV-1 Tat protein increases transcriptional initiation and stabilizes elongation. Cell 59: 283-292.

-1990. Synergy between HIV-1 Tat and adenovirus EIA is principally due to stabilization of transcriptional elongation. Genes \& Dev. 4: 2397-2408.

Marciniak, R.A., M.A. Garcia-Blanco, and P.A. Sharp. 1990a. Identification and characterization of a HeLa nuclear protein that specifically binds to the trans-activation-response (TAR) element of human immunodeficiency virus. Proc. Natl. Acad. Sci. 87: 3624-3628.

Marciniak, R.A., B.J. Calnan, A.D. Frankel, and P.A. Sharp. 1990b. HIV-1 Tat protein trans-activates transcription in vitro. Cell 63: 791-802.

Muesing, M.A., D.H. Smith, and D.J. Capon. 1987. Regulation of mRNA accumulation by a human immunodeficiency virus trans-activator protein. Cell 48: 691-701.

Nakanishi, Y., Y. Mitsuhashi, K. Sekimizu, H. Yokoi, Y. Tanaka, M. Horikoshi, and S. Natori. 1981. Characterization of three proteins stimulating RNA polymerase II. FEBS Lett. 130: $69-72$.

Neuman de Vegvar, H.E., E. Lund, and J.E. Dahlberg. 1986. 3' end formation of U1 snRNA precursors is coupled to transcription from snRNA promoters. Cell 47: 259-266.

Okamoto, T. and F. Wong-Staal. 1986. Demonstration of virusspecific transcriptional activator(s) in cells infected with HTLV-III by an in vitro cell-free system. Cell 47: 29-35.

Okamoto, T., T. Benter, S.F. Josephs, M.R. Sadaie, and F. WongStaal. 1990. Transcriptional activation of the long-terminal repeat of human immunodeficiency virus in vitro. Virology 177: 606-614.

Pavlakis, G.N. and B.K. Felber. 1990. Regulation of expression of human immunodeficiency virus. New Biologist 2: 20-31.

Peterlin, B.J., P.A. Luciw, P.J. Barr, and M.D. Walker. 1986. Elevated levels of mRNA can account for the trans-activation of human immunodeficiency virus. Proc. Natl. Acad. Sci. 83: 9734-9738.

Pognonec, P., H. Kato, H. Sumimoto, M. Kretzschmar, and R.G. Roeder. 1991. A quick procedure for purification of functional recombinant proteins over-expresseed in $E$. coli. $\mathrm{Nu}$ cleic Acids Res. 19: 6650.

Price, D.H., A.E. Sluder, and A.L. Greenleaf. 1989. Dynamic interaction between a Drosophila transcription factor and RNA polymerase II. Mol. Cell. Biol. 9: 1465-1475.

Reinberg, D. and R.G. Roeder. 1987. Factors involved on specific transcription by mammalian RNA polymerase II. I. Biol. Chem. 262: 3331-3337.

Resnekov, O., M. Kessler, and Y. Aloni. 1989. RNA secondary structure is an integral part of the in vitro mechanism of attenuation in simian virus 40. J. Biol. Chem. 264: 99539959.

Rice A.P. and M.B. Mathews. 1988. Transcriptional but not translational regulation of HIV-1 by the tat gene product. Nature 332: 551-553.

Roberts, J.W. 1988. Phage lambda and the regulation of transcription termination. Cell 52: 5-6.

Rosen, C.A., J.G. Sodroski, and W.A. Haseltine. 1985. The location of cis-acting regulatory sequences in the human T-cell lymphotropic virus type III (HTLV-III/LAV) long terminal repeat. Cell 41: 813-823.

Rosen, C.A., J.G. Sodroski, W.C. Goh, A.I. Dayton, J. Lippke, and W.A. Haseltine. 1986. Post-transcriptional regulation accounts for the trans-activation of human T-lymphotropic virus type III. Nature 319: 555-559.

Roy, S., U. Delling, C.-H. Chen, C.A. Rosen, and N. Sonenberg. 1990. A bulge structure in HIV-1 TAR RNA is required for
Tat binding and Tat-mediated trans-activation. Genes \& Dev. 4: 1365-1373.

Ruben, S., A. Perkins, R. Purcell, K. Joung, R. Sia, R. Burghoff, W.A. Haseltine, and C.A. Rosen. 1989. Structural and functional characterization of human immunodeficiency virus tat protein. I. Virol. 63: 1-8.

Sekimizu, K., N. Kobayashi, D. Mizuno, and S. Natori. 1976. Purification of a factor from Ehrlich ascites tumor cells specifically stimulating RNA polymerase II. Biochemistry 15: 5064-5070.

Selby, M.J. and B.M. Peterlin. 1990. Trans-activation by HIV-1 Tat via a heterologous RNA binding protein. Cell 62: 769776.

SenGupta, D.N., B. Berkhout, A. Gatignol, A. Zhou, and R.H. Silverman. 1990. Direct evidence for translational regulation by leader RNA and Tat protein of human immunodeficiency virus type 1. Proc. Natl. Acad. Sci. 87: 7492-7496.

Sharp, P.A. and R.A. Marciniak. 1989. HIV TAR: An RNA enhancer? Cell 59: 229-230.

Sodroski, J., R. Patarca, C. Rosen, F. Wong-Staal, and W. Haseltine. 1985. Location of the trans-activating region on the genome of human T-cell lymphotropic virus type III. Science 229: 74-77.

Sopta, M., R.W. Carthew, and J. Greenblatt. 1985. Isolation of three proteins that bind to mammalian RNA polymerase II. I. Biol. Chem. 260: 10353-10360.

Sopta, M., Z.F. Burton, and J. Greenblatt. 1989. Structure and associated DNA-helicase activity of a general transcription initiation factor that binds to RNA polymerase II. Nature 341: 410-414.

Southgate, C. and M.R. Green. 1991. The HIV-1 Tat protein activates transcription from an upstream DNA-binding site: Implications for Tat function. Genes \& Dev. 5: 2496-2507.

Southgate, C., M.L. Zapp, and M.R. Green. 1990. Activation of transcription by HIV-1 Tat protein tethered to nascent RNA through another protein. Nature 345: 640-642.

Sumimoto, H., Y. Ohkuma, T. Yamamoto, M. Horikoshi, and R.G. Roeder. 1990. Factors involved in specific transcription by mammalian RNA polymerase II: Identification of general transcription factor TFIIG. Proc. Natl. Acad. Sci. 87: 9158 9162.

Weeks, K.M., C. Ampe, S.C. Schultz, T.A. Steitz, and D.M. Crothers. 1990. Fragments of the HIV-1 Tat protein specifically bind TAR RNA. Science 249: 1281-1285.

Weil, P.A., D.S. Luse, J. Segall, and R.G. Roeder. 1979. Selective and accurate initiation of transcription at the $\mathrm{Ad} 2$ major late promoter in a soluble system dependent on purified RNA polymerase II and DNA. Cell 18: 469-484. 


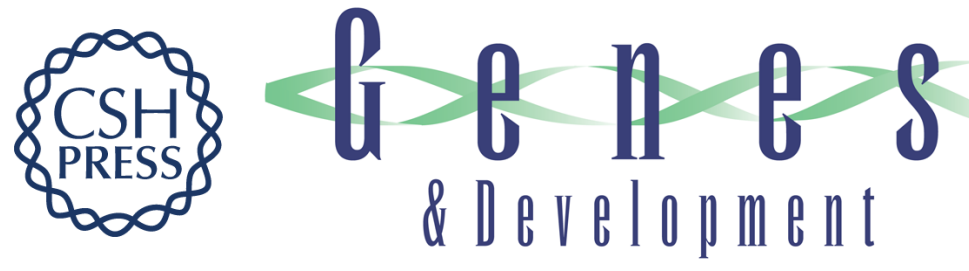

\section{HIV-1 Tat acts as a processivity factor in vitro in conjunction with cellular elongation factors.}

$\mathrm{H}$ Kato, H Sumimoto, P Pognonec, et al.

Genes Dev. 1992, 6:

Access the most recent version at doi:10.1101/gad.6.4.655

References This article cites 67 articles, 28 of which can be accessed free at:

http://genesdev.cshlp.org/content/6/4/655.full.html\#ref-list-1

License

Email Alerting

Service

Receive free email alerts when new articles cite this article - sign up in the box at the top right corner of the article or click here.

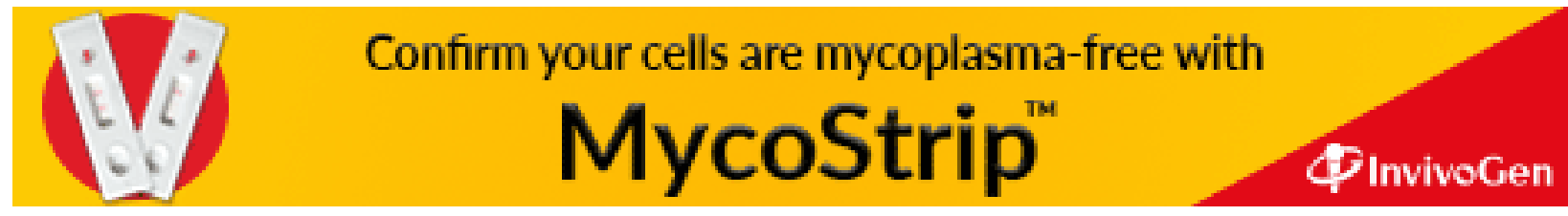

